\title{
Clinical Disorders of Memory
}


CRITICAL ISSUES IN PSYCHIATRY

An Educational Series for Residents and Clinicians

Series Editor: Sherwyn M. Woods, M.D., Ph.D.

University of Southern California School of Medicine

Los Angeles, California

Recent volumes in the series:

ADULT DEVELOPMENT: A New Dimension on Psychodynamic Theory and Practice

Calvin A. Colarusso, M.D., and Robert A. Nemiroff, M.D.

CLINICAL DISORDERS OF MEMORY

Aman U. Khan, M.D.

CLINICAL PERSPECTIVES ON THE SUPERVISION OF

PSYCHOANALYSIS AND PSYCHOTHERAPY

Edited by Leopold Caligor, Ph.D., Philip M. Bromberg, Ph.D.,

and James D. Meltzer, Ph.D.

CONTEMPORARY PERSPECTIVES ON PSYCHOTHERAPY WITH

LESBIANS AND GAY MEN

Edited by Terry Stein, M.D., and Carol Cohen, M.D.

DIAGNOSTIC AND LABORATORY TESTING IN PSYCHIATRY

Edited by Mark S. Gold, M.D., and A. L. C. Pottash, M.D.

DRUG AND ALCOHOL ABUSE: A Clinical Guide to Diagnosis

and Treatment, Second Edition

Marc A. Schuckit, M.D.

EMERGENCY PSYCHIATRY: Concepts, Methods, and Practices

Edited by Ellen L. Bassuk, M.D., and Ann W. Birk, Ph.D.

ETHNIC PSYCHIATRY

Edited by Charles B. Wilkinson, M.D.

EXTRAORDINARY DISORDERS OF HUMAN BEHAVIOR

Edited by Claude T. H. Friedmann, M.D., and Robert A. Faguet, M.D.

MARITAL THERAPY: A Combined Psychodynamic-Behavioral Approach R. Taylor Segraves, M.D., Ph.D.

MOOD DISORDERS: Toward a New Psychobiology

Peter C. Whybrow, M.D., Hagop S. Akiskal, M.D., and

William T. McKinney, Jr., M.D.

THE RACE AGAINST TIME: Psychotherapy and Psychoanalysis

in the Second Half of Life

Edited by Robert A. Nemiroff, M.D., and Calvin A. Colarusso, M.D.

SCHIZOPHRENIA

John S. Strauss, M.D., and William T. Carpenter, Jr., M.D.

TREATMENT INTERVENTIONS IN HUMAN SEXUALITY

Edited by Carol C. Nadelson, M.D., and David B. Marcotte, M.D.

A Continuation Order Plan is available for this series. A continuation order will bring delivery of each new volume immediately upon publication. Volumes are billed only upon actual shipment. For further information please contact the publisher. 


\section{Clinical Disorders of Memory}

Aman U. Khan, M.D.

Southern Illinois University School of Medicine Springfield Illinois 


\section{Library of Congress Cataloging in Publication Data}

Khan, Aman U.

Clinical disorders of memory.

(Critical issues in psychiatry)

Includes bibliographies and index.

1. Memory, Disorders of. 2. Memory, Disorders of-Etiology. 3. Memory, Effect of drugs on. I. Title. II. Series. [DNLM: 1. Memory-physiology. 2. Memory Disorders. WM $173.7 \mathrm{~K} 45 \mathrm{c}]$

BF376.K33 1986

616.8

86-18708

ISBN-13: 978-1-4684-5130-6

e-ISBN-13: 978-1-4684-5128-3

DOI: $10.1007 / 978-1-4684-5128-3$

(C) 1986 Plenum Publishing Corporation

Softcover reprint of the hardcover 1st edition 1986

233 Spring Street, New York, N.Y. 10013

Plenum Medical Book Company is an imprint of Plenum Publishing Corporation

All rights reserved

No part of this book may be reproduced, stored in a retrieval system, or transmitted in any form or by any means, electronic, mechanical, photocopying, microfilming, recording, or otherwise, without written permission from the Publisher 


\section{Preface}

Memory is essential for the retention of learning. In the presence of memory deficits, new learning is impaired and performance of previously learned habits deteriorates. What is the nature of memory? Where does it reside in the brain? What biological events are associated with the formation and retrieval of memory? These questions are explored in the first chapter of this volume. The answers are not final, but we have learned a great deal about memory processes during the past few decades.

Memory is influenced by most of the pathological processes that influence the brain such as infection, trauma, cerebrovascular disorders, and metabolic and degenerative diseases. The nature and course of memory impairment are unique for each of the disorders and are fairly distinguishable. More than fifty conditions are known to cause dementia, which now affects several million Americans. In Alzheimer's disease, memory disorder predominates for two to three years before other intellectual functions are affected. Many neurological diseases, such as Huntington's disease, Friedreich's ataxia, and multiple sclerosis, are associated with progressive memory deficits.

Forgetting is a problem that becomes progressively worse with age. Most individuals in their forties begin to experience some difficulty in quick recall of past events. By age sixty definite changes are evident in the process of registration, storage, and recall of memory. At this age the material that is to be remembered is processed more slowly, stored less firmly, and poorly recalled.

Functional disorders of memory have fascinated psychologists for centuries. Posthypnotic amnesia has been attributed to functional separation or dissociation in different types of mental processes. Hypnotically induced age regression highlights selective activities of childhood and does not involve total reinstitution of childhood mental processes and memories. The dissociative disorders of memory, such as psychogenic amnesia, fugue, depersonalization, and multiple personality, have moved up to the forefront of scientific investigation. Better understanding of memory impairment in depression and schizophrenia has led to innovative therapeutic interventions. 
A large number of drugs have been shown to influence memory. Clinicians need to become more aware of the memory-impairing effects of various drugs, especially in the treatment of the elderly with marginal memory functions. Chronic use of alcohol, even in small amounts, appears to have an accumulative effect on the nervous system, producing progressive impairment of intellectual and memory functions.

The treatment of memory disorders is just beginning to receive the attention of clinicians and researchers. Memory clinics have been established in various medical centers. A large number of drugs, such as cholinergic drugs, stimulants, and nootropic drugs, are being experimentally employed in an effort to improve memory deficits. Other methods of treatment, such as surgical procedures to improve brain blood supply and rehabilitation methods to help older people better organize their daily activities, have become important tools in the management of memory disorders.

ACKNOWLEDGMENTS. Jean Brown and Kathy Ruffer contributed greatly to the preparation of this book with their organization and typing skills. I am also very grateful to Joseph Cataio, who spent a great deal of time in library research and in the editing of the manuscript.

Springfield, Illinois

Aman U. Khan 


\section{Contents}

1. Nature of Memory $\ldots \ldots \ldots \ldots \ldots \ldots \ldots \ldots \ldots \ldots \ldots \ldots \ldots \ldots \ldots \ldots, 1$

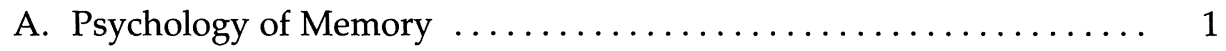

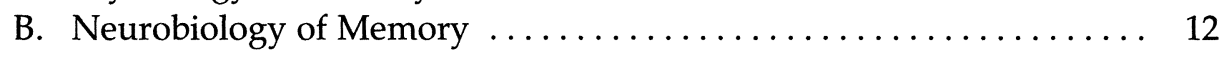

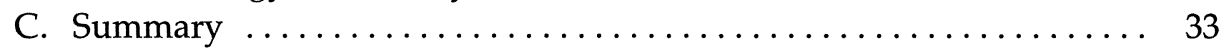

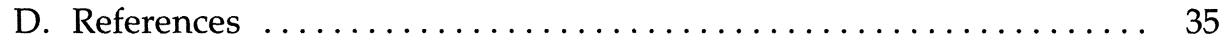

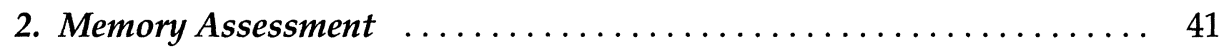

A. Single Tests of Memory (Verbal) $\ldots \ldots \ldots \ldots \ldots \ldots \ldots \ldots \ldots, 41$

B. Single Tests of Memory (Nonverbal) $\ldots \ldots \ldots \ldots \ldots \ldots \ldots \ldots \ldots \ldots$

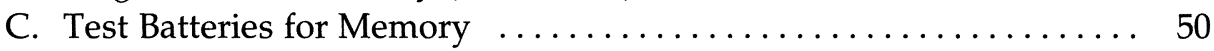

D. Neuropsychological Test Batteries $\ldots \ldots \ldots \ldots \ldots \ldots \ldots \ldots \ldots \ldots \ldots \ldots$

E. Questionnaires to Assess Memory $\ldots \ldots \ldots \ldots \ldots \ldots \ldots \ldots \ldots \ldots \ldots \ldots$

F. Clinical Examination of Memory $\ldots \ldots \ldots \ldots \ldots \ldots \ldots \ldots \ldots \ldots \ldots \ldots \ldots$

G. Specific Rating Scales and Inventories $\ldots \ldots \ldots \ldots \ldots \ldots \ldots \ldots . \ldots \ldots$

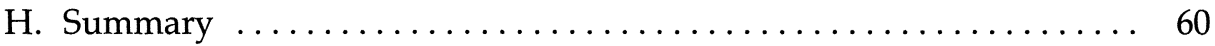

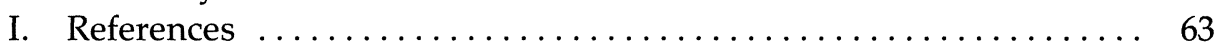

3. Drugs Influencing Learning and Memory $\ldots \ldots \ldots \ldots \ldots \ldots \ldots$

A. Introduction and Historical Overview $\ldots \ldots \ldots \ldots \ldots \ldots \ldots \ldots, 67$

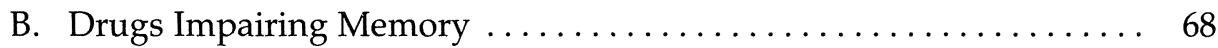

C. Drugs Facilitating Memory $\ldots \ldots \ldots \ldots \ldots \ldots \ldots \ldots \ldots \ldots \ldots \ldots \ldots \ldots$

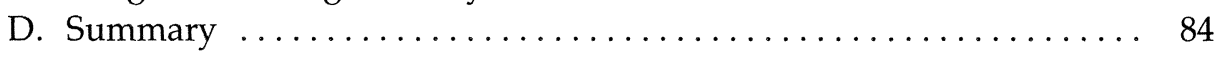

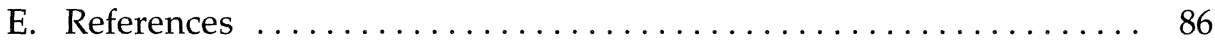


4. Alcohol and Memory Impairment .................. 89

A. Social Drinking $\ldots \ldots \ldots \ldots \ldots \ldots \ldots \ldots \ldots \ldots \ldots \ldots \ldots$

B. Acute Alcoholic Intoxication $\ldots \ldots \ldots \ldots \ldots \ldots \ldots \ldots \ldots \ldots \ldots \ldots \ldots \ldots \ldots$

C. Chronic Alcoholism ............................ 94

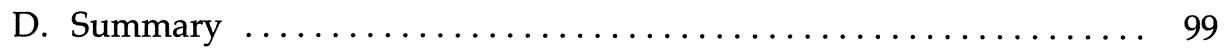

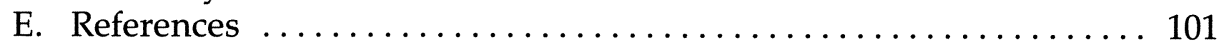

5. Role of Neuropeptides in Memory ................... 105

A. Noradrenaline and Dopamine System $\ldots \ldots \ldots \ldots \ldots \ldots$

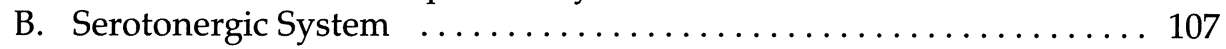

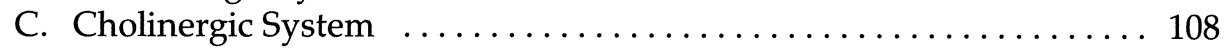

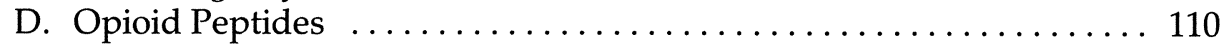

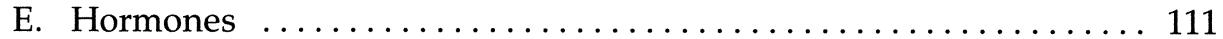

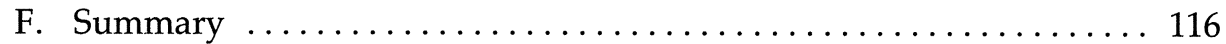

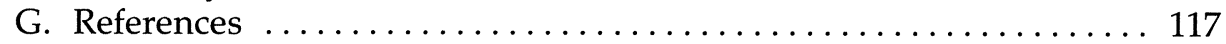

6. Memory in Degenerative Diseases of the Nervous System . . . . . . 121

A. Alzheimer's Disease . . . . . . . . . . . . . . . . . . . . . 122

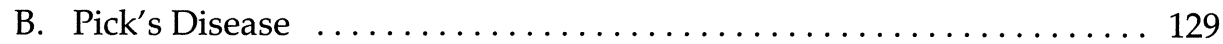

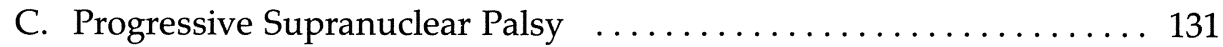

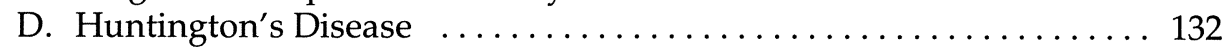

E. Wilson's Disease . . . . . . . . . . . . . . . . . . . . . 135

F. Hallervorden-Spatz Syndrome . . . . . . . . . . . . . . . . 137

G. Parkinson's Disease ......................... 137

H. Amyotrophic Lateral Sclerosis and Parkinsonian Dementia

Complex of Guam ............................. 141

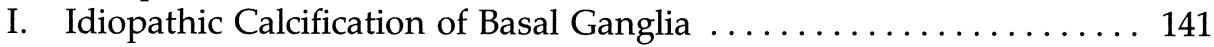

J. Spinocerebellar Degenerations . . . . . . . . . . . . . . . . 142

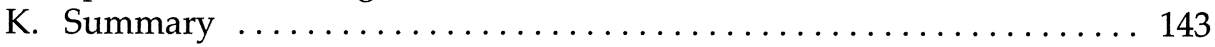

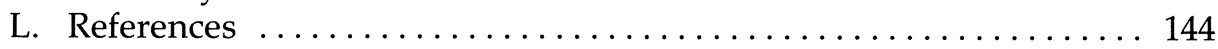

7. Memory in Cerebrovascular Disorders ................. 149

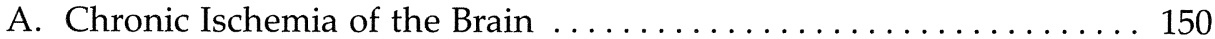

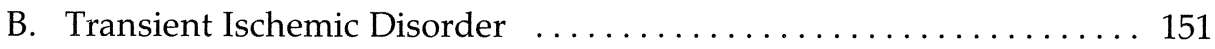

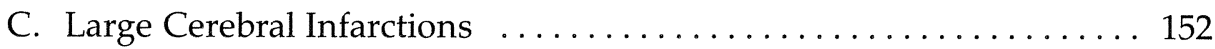

D. Multi-infarct Dementia . . . . . . . . . . . . . . . . . . . . . . 154

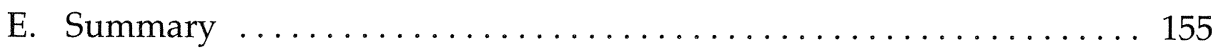

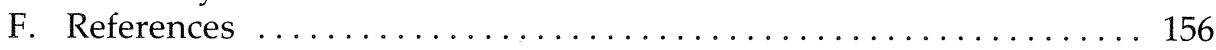




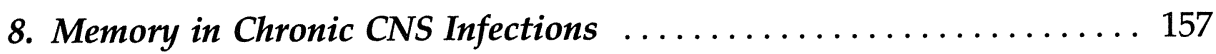

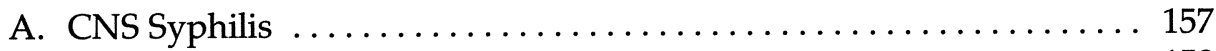

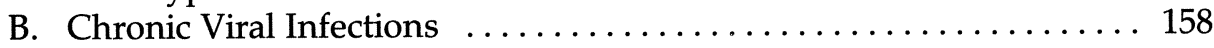

C. Subacute Sclerosing Panencephalitis .................. 159

D. Progressive Multifocal Leukoencephalopathy ............... 159

E. Transmissible Spongioform Encephalopathies .............. 160

F. Long-term Sequelae of Bacterial Meningitis in Children . . . . . . . . 161

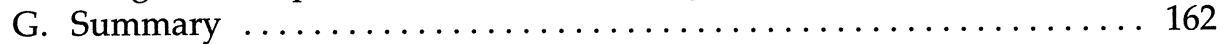

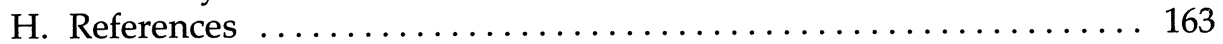

9. Memory in Chronic Diseases ...................... 165

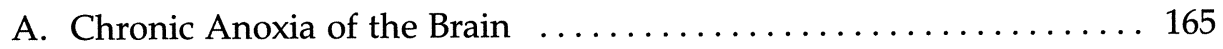

B. Cardiac Diseases ................................ 165

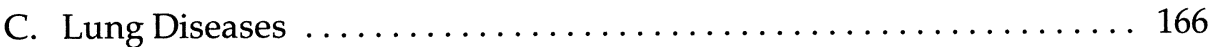

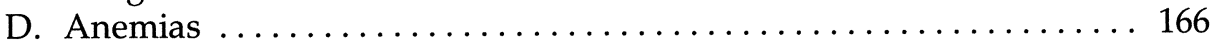

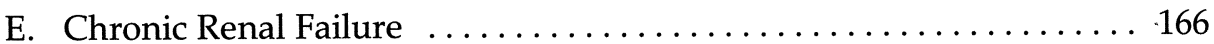

F. Chronic Liver Diseases . . . . . . . . . . . . . . . . . . . 168

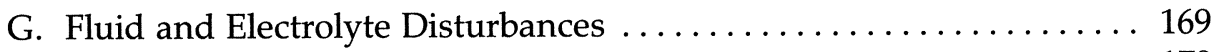

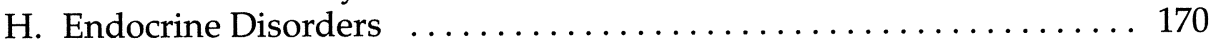

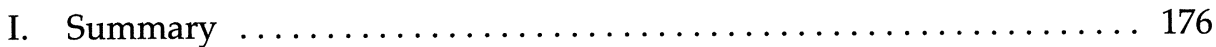

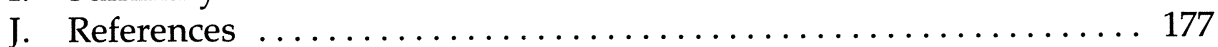

10. Memory in Head Trauma ...................... 179

A. Severity of Injury $\ldots \ldots \ldots \ldots \ldots \ldots \ldots \ldots \ldots \ldots \ldots \ldots \ldots \ldots \ldots \ldots \ldots \ldots \ldots$

B. Focal versus Diffuse Brain Damage $\ldots \ldots \ldots \ldots \ldots \ldots \ldots \ldots \ldots . \ldots \ldots$

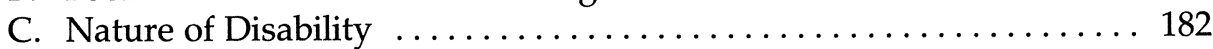

D. Recovery of Physical and Mental Functions $\ldots \ldots \ldots \ldots \ldots \ldots \ldots$

E. Memory Disorders from Head Trauma . . . . . . . . . . . . . . 184

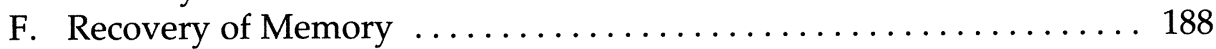

G. Nature of Impaired Memory in Head Trauma . . . . . . . . . . . 192

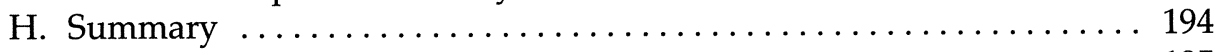

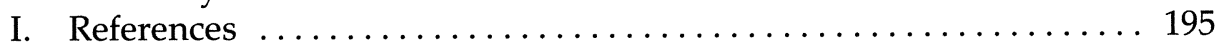

11. Functional Disorders of Memory .................... 199

A. Memory Functions in Depression $\ldots \ldots \ldots \ldots \ldots \ldots \ldots \ldots$

B. Memory Functions in Schizophrenia . .................. 201

C. Memory Dysfunction in Autistic Children . . . . . . . . . . . . . . 202

D. Memory Impairment in Dissociative Disorders . . . . . . . . . . . 203 


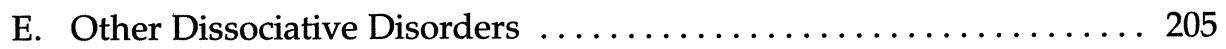

F. Dream Memory and Dream Amnesia .................. 209

G. Hypnosis and Memory Dysfunctions $\ldots \ldots \ldots \ldots \ldots \ldots \ldots \ldots \ldots \ldots$

H. Memory Loss Induced by Electroconvulsive Therapy ......... 214

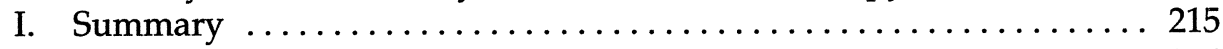

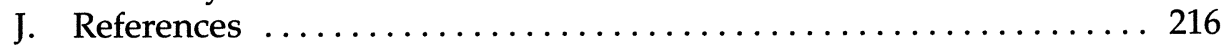

12. Memory Changes with Aging . . . . . . . . . . . . . . 219

A. Psychological Aspects of Memory Changes with Aging . . . . . . 219

B. Other Factors Affecting Memory in the Elderly . . . . . . . . 228

C. Biological Aspects of Aging and Memory . . . . . . . . . . . . . 229

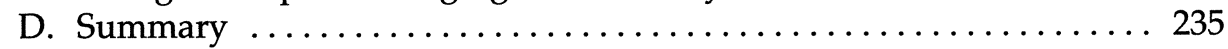

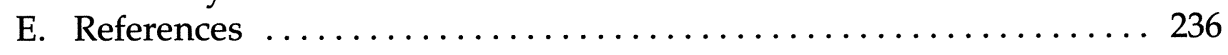

13. Treatment Strategies for Memory Disorders ............ 239

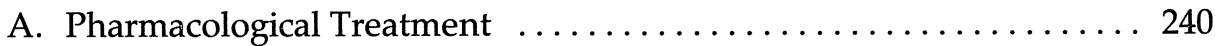

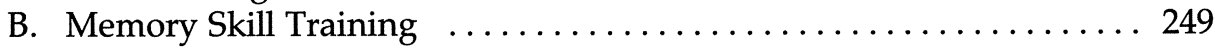

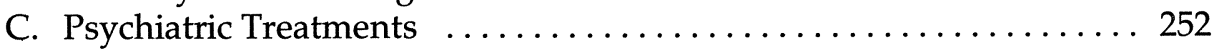

D. Environmental and Reality Orientation Program ........... 252

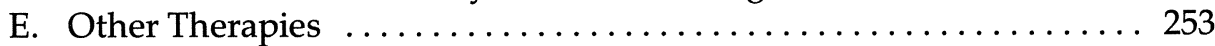

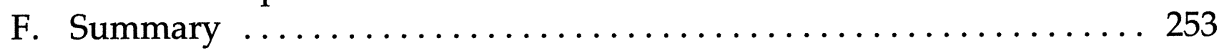

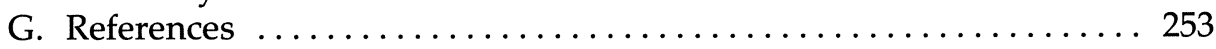

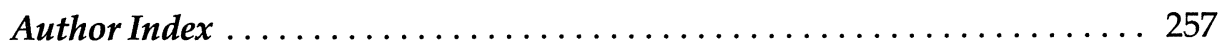

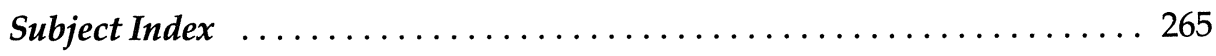




\section{Clinical Disorders of Memory}

